\title{
The Wayward Money Supply: A Post-Mortem of 1982
}

\author{
R. W. HAFER and SCOTT E. HEIN
}

(․․․

B INCE the Federal Reserve changed its operating procedures in late 1979 to achieve greater control over monetary aggregate growth, money stock (M1) growth has been highly volatile.' This volatility continued through 1982: M1 grew at annual rates of 16.7 percent from November 1981 to January 1982, 3.0 percent from January to July 1982, and 13.1 percent from July to December 1982.

Increased volatility in money growth can produce adverse economic consequences under certain conditions. Both economic theory and evidence suggest that substantial short-run deviations in money growth from its longer-run trend affect the growth of spending and real economic activity. ${ }^{2}$ For example, as chart 1 illus-

An earlier tersion of this paper was presented at a Business Economics and Public Policy Workshop at Indiana University. We would like to thank all the participants for helpfal comments, especially Lawrence S. Davidson and Michele Fratianni.

'For example, the standard deviation of quarterly $M I$ growth from IV/1979 to IV/1982 is 5.91. In contrast, the standard deviation for Ml growth from IV/1976 to III/1979 was 1.45

Some may argue that this conparison is misleading, because the fuctuations in recent years likely will flatten out over time as evolving seasonal patterns are captured in the recalculation of seasonal factors. Others, however, have been highly skeptical of revisions in seasonal factors, arguing that such revisions artificially smooth away outliers. For example, William Poole and Charles Lieberman, "Improving Monetary Control," Brookings Papers on Economic Activity (2:1972), pp. 293-335, have stated that "one of the dangers of the $X-11$ model is that outliers are all too easily explained away by a superficial appeal to changirg seasonals" ( $p$. 332).

${ }^{2}$ This type of analysis was presented ftrst by Clark Warburton, "Bank Reserves and Business Fluctuations," Journal of the American Statistical Association (December 1948), pp. 547-58, reprinted in Clark Warburton, Depression, Infation, and Monetary Policy: Selected Papers 1945-1953 (The Johns Hopkins Press, 1966), pp. 36-47. Analyses in this tradition also are presented in Milton Friednan and Anna J. Schwartz, "Money and Busiaess Cycles," Revietw of Economics and Statistics (Supplement: February 1963), pp. 32-78; William Poole "The Relationship of Monetary Decelerations to Business Cycle Peaks: Another Look at the Evidence," Journal of Finance (June 1975), pp. 697-712, and most recently Milton F riedman, "Misleading Unanimity," Newsweek (February $7,1983)$, p. 56 trates, large negative deviations of money growth from its trend have been associated with each period of economic decline since 1958.

The increased volatility in money growth has led many observers to question whether the Federal Reserve has the ability to control money growth adequately. ${ }^{3}$ Some analysts have suggested that the Fed must make certain technical changes, such as implementing contemporaneous reserve accounting, altering discount rate policy and restructuring reserve requirements, to better control the money stock.

This article examines whether more stable growth of the money stock could have been achieved in 1982 without any of the proposed technical changes. To this end, two simple money stock control procedures are used to simulate money growth in 1982. One procedure involves increasing the monetary base at a steady rate. The other involves changing base growth to offset expected money multiplier changes. The latter procedure is shown to achieve the hypothetical annual growth target with little volatility in quarterly money growth.

\footnotetext{
${ }^{3}$ For contrasting views on this issue, see Milton Friedman, "The Wayward Money Supply, "Newsweek (Decenber 27, 1982), p. 58. "The Pitfalls of Mechanical Monetarism," The Morgan Guaranty Survey (February 1981), pp. 8-13; and Milton Friedman, "Improving Monetary Policy," Newsweek (July 28, 1980), p. 60. More sophisticated analyses are presented in Board of Covernors of the Federal Reserve System, New Monetary Control Procedures, Federal Reserve Staff Study, vols. 1 and 2 (Board of Covernors, 1981).

One argument is that "large swings" in the demand for money are direct causes of observed variability in money growth. For example, see "Statement by Lyle Gramley, member, Board of Governors of the Federal Reserve System, before the Subcommittee on Domestic Monetary Policy of the House Committee on Banking, Finance and Urban Affairs, March 3, 1982,"Federal Reserve Bulletin (March 1982), pp. 174-78. For an alternative analysis, see Scott E. Hein, "Short-Run Money Growth Volatility: Evidence of Misbehatving Money Demand?" this Review (Junet July 1982), pp. 27-36; and Kenneth C. Froewiss, "Speaking Softly But Carrying a Big Stick," Economic Research (Goldman Sachs, December 1982)
} 
Chart 1

Rates of Change of Money Stock (MI)



$\lfloor$ Two-quarter rate of change.

12 Twenty-quarter rate of change; data prior to 1 st quarter 1964 are $M 1$ on the old basis.

Shaded areas represent periods of bushess recssions. $1989-82$ mough is tentuthe. 
Table 1

M1 Growth Rates in 1982

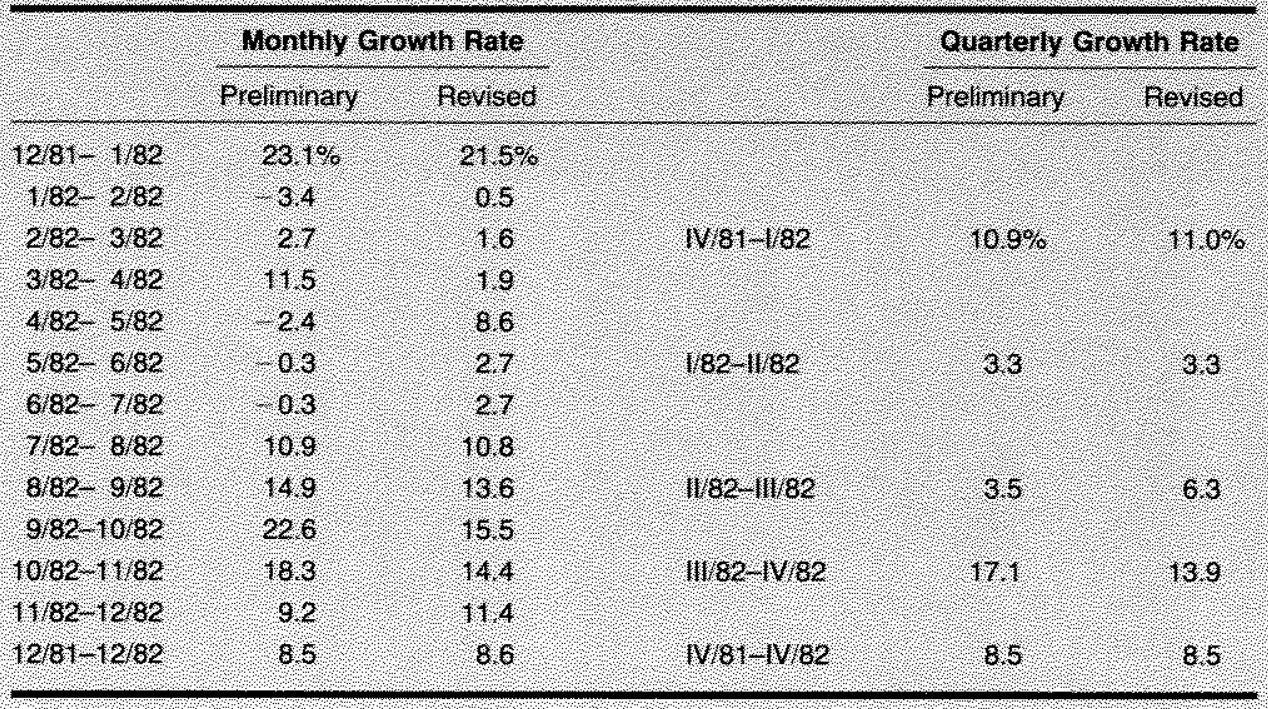

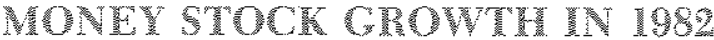

Table 1 lists M1 growth for 1982 on a monthly and quarterly basis. The respective growth rates are calculated for both preliminary data and the recently revised data, which incorporate both benchmark revisions and revised estimates of seasonal factors. It is apparent that the recent revisions have smoothed substantially the fluctuations in both monthly and quarterly money growth. With the exception of March and April, the revised monthly growth rates all are closer to the average growth rate over the period. Thus, the standard deviation of the monthly growth rates is reduced substantially by the revisions: 6.84 vs. 9.59 . Similarly, the standard deviation of the quarterly growth rates is 4.73 for the revised series and 6.62 for the preliminary series.

This suggests that at least part of the volatility in money growth last year is attributable to poor preliminary data. For example, the revised numbers indicate that the original estimates of strong money growth in April, October and November all were exaggerated. Similarly, the original estimates of negative money stock growth in February, May, June and July were incorrect; the revised data show that money growth was positive during these months.

The fact that revisions in money stock measures have reduced the volatility in money growth is comforting, ex post. For a policymaker making decisions in 1982 , however, the extent of the revisions was unknown and the volatility of observed money growth could have been considered excessive. Because this present analysis addresses the issue of reducing the volatility of money growth in an ongoing policy setting, we ignore the recent revisions in money stock numbers; policymakers would not have had this information in 1982 when decisions were being made.

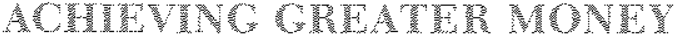

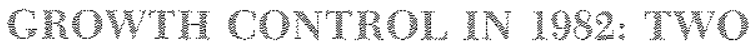

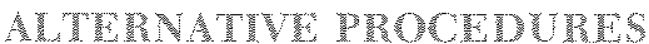

Could the Fed have achieved a more stable pattern of money growth in 1982 than that evidenced by table

\footnotetext{
This approach is supported by a recent Federal Reserve Board report dealing with the problem of seasonal adjustment. In that report, it is stated that "since the original projections [of seasonal factors] are what policymakers and other users of the data have to work with currently in making decisions, the revised data may give an erroneous impression, after the fact, of what the basis for the decision was. "Board of Governors of the Federal Reserve System, Seasonal Adjustment of the Monetary Aggregates: Report of the Committee of Experts on Seasonal Adjustment Techniques (Federal Reserve Board, 1981), p. 35. Cited in David A. Pierce, "Seasonal Adjustment of the Monetary Aggregates: Summary of the Federal Reserve's Committee Report," Journal of Business and Economic Statistics (January 1983), pp. 37-42. Our treatment only adds realism to the simulations carried out. It does not affect any sub. stantive conclusions about comparing alternative operating procedures: If revised data are used, the constant-base-growth strategy still results in quarterly money growth volatility in 1982 similar to that indicated by revised data, but much greater than that associated with the multiplier monitoring approach.
} 
1? This question is examined by analyzing two alterna* tive control procedures, each controlling Ml growth by altering the adjusted monetary base (hereafter referred to as base). ${ }^{\overline{2}}$

The first procedure involves simply holding the growth of the base constant over the year. ${ }^{6}$ Because there generally is a direct relationship between changes in the growth rate of the base and the money stock, a constant rate of base growth will, on average, yield a predictable growth rate of money. This approach produces stable short-run Ml growth, however, only if the rate of change of the money multiplier - the connecting link between changes in the base and money - remains constant over time. Although this typically is the case over longer periods of time, it is not true over time spans as short as a month or a quarter. Thus, even though base and money growth are closely related over periods of a year or more, short-run money multiplier changes can cause short-run money growth to deviate substantially from any particular base growth. This is the primary weakness with this procedure.

The second control procedure alleviates the short. run discrepancies between base and M1 growth by anticipating changes in the multiplier and, then, offsetting them by appropriate changes in base growth. This

${ }^{5}$ The base is controlled essentially by Fed actions. On the issue of the Fed's ability to control the base, see Anatol B. Balback, "How Controllable is Money Growth?" this Review (April 1981), pp. $3-12$

That study found that "the Federal Reserve can control the monetary base even on a weekly basis if it so desires. There is, of course, no question that it can do so over longer periods of time." In this light, no adjustment in achieving a monetary base objective is made. On measuring the base (on an adjusted basis), see $R$. Alton Gilbert, "Revision of the St. Louis Federal Reserve Adjusted Monetary Base," this Review (December 1980), pp. 3-10; and John A. Tatom, "Issues in Measuring An Adjusted Monetary Base," this Review (December 1980), pp, 11-29.

${ }^{E}$ This approach has been advocated in recent statements of the Shadow Open Market Committee. This is because "[C]urrent institutional changes have less effect on the growth of the base than on most other aggregates." See "Policy Statement of the Shadow Open Market Committee, March 16, 1981,"Annual Report, Center for Research in Goverment Policy \& Business (June 1981), pp $31-35$, especially pp. $33-34$. This advocacy also is found in the September 14, 1981, "Policy Statement." This argument presupposes that stable Ml growth may not be desirable with all of the current institutional changes. In contrast, the present article presupposes that stable $\mathrm{M} 1$ growth is desirable and seeks to determine the extent to which it may be achieved. Of course, the desirability of stable money growth depends on the stability of the demand for money, a matter not addressed in this article. For a study that also recommends base instead of money stock targeting, see Leonall $\mathrm{C}$ Andersen and Denis S. Karnosky, "Some Considerations in the Use of Monetary Aggregates for the Implementation of Monetary Policy," this Review (September 1977), pp. 27. procedure involves using one-period-ahead multiplier forecasts to determine the extent to which the base should be expanded or contracted. ${ }^{7}$ Two methods of forecasting money multiplier developments are con" sidered for this procedure.

\section{The Constant-Base-Crowth Procedure}

Analysis of Ml growth and its volatility requires choosing some desired target level or range. In the analysis which follows, the top of the announced 1982 annual M1 target range -5.5 percent growth - was selected as a hypothetical operating target. ${ }^{8}$ Table 2 enumerates the desired monthly level of M1 that would be consistent with achieving this growth target with no short-run variation in Ml growth (see column 1). Because the money stock is the product of the multiplier and the base, the growth rate of M1 (M1) is approximately equal to the growth rate of the money multiplier $(\dot{\mathrm{m}})$ plus the growth rate of the base $(\mathrm{A} \dot{\mathrm{M} B})$ :

\section{(1) $\quad \dot{M l}=\dot{\mathrm{m}}+\mathrm{A} \dot{\mathrm{M} B}$.}

As equation 1 shows, it is necessary to predict $\dot{m}$ in order to determine the appropriate $\mathrm{AMB}$ to provide. During the last 12 years $(1970-81)$, the level of the money multiplier has been declining on average; $\dot{m}$ has averaged -1.1 percent. Thus, over this period, base growth, on average, exceeded Ml growth by 1.1 percent. This was assumed to continue in 1982. To achieve the desired $\mathrm{M} 1$ growth of 5.5 percent under the base control procedure considered here, therefore, the money multiplier is "predicted" to decline at a 1.1 percent rate during 1982. Given the assumed rate of decline in the money multiplier, a constant 6.6 percent rate of increase in the base would be needed to yield the targeted 5.5 percent money growth. This required base path (in levels) is shown in column 3 of table 2 .

The constant-base-growth strategy would have resulted in stable money growth only if the money multiplier declined in a steady fashion as presumed. During 1982, however, the money multiplier was highly volatile by historical standards (see column 2 of table 2 ). For example, based on original data, the difference between the maximum and minimum level of the mul-

\footnotetext{
${ }^{7}$ A similar argument for using money multiplier forecasts as a basis for policy actions is presented in Balbach, "How Controllable is Money Growth?" and James M. Johanzes and Robert H. Rasche, "Can the Reserves Approach to Monetary Control Really Work?" Journal of Money, Credit and Banking (August 1981), pp. 298-313.

sIt should be noted that the Federal Open Market Committee temporarily ended its practice of adopting short-run targets for M1 in October 1982, because of difficulties in interpreting its behavior.
} 


\section{Table 2}

\section{M1 Growth Under Constant 6.6 Percent Base Growth (seasonally adjusted, original data)}

\begin{tabular}{|c|c|c|c|c|c|c|}
\hline Period & Targeted WII & Actual multipler & Simulated base & sinumated Mi & $\begin{array}{l}\text { Smumat } \\
\text { Mornily }\end{array}$ & growtrifate \\
\hline & 111 & (2) & $(6)$ & (4) & (5) & (6) \\
\hline 126 & & 25951 & & & & \\
\hline 1182 & 8,429 & 26142 & 17700 & 84465 & $16 \%$ & \\
\hline 2262 & 444.9 & 25826 & $171 \%$ & 4429 & 893 & $178 \%$ \\
\hline 362 & 4468 & 25809 & 1726 & 445.5 & $7 \%$ & \\
\hline 4182 & 4488 & 25887 & 1736 & 4485 & 84 & \\
\hline 5.82 & 4509 & 25566 & 1745 & $4 \times 6,3$ & 6.2 & 15 \\
\hline 682 & 16529 & 25874 & 1754 & 445.1 & .27 & \\
\hline 782 & 4540 & 25354 & 176,4 & 4472 & 38 & \\
\hline 808 & 456.9 & 2.5368 & $177 \%$ & 4501 & 81 & 42 \\
\hline 9002 & 4890 & 25598 & 1782 & 4562 & 175 & \\
\hline 1098 & 1610 & 25893 & 1792 & 464,0 & 226 & \\
\hline 11162 & 466, & 26112 & 1802 & $4+1$ & 197 & 110 \\
\hline $12 / 82$ & 465 & 26096 & $181 /$ & 4726 & 49 & \\
\hline Simila & rowh bec & 1981 to Decen & $7.2 \%$ & & & \\
\hline Acturat & Swlt. Dec & 1981 to becemb & $8.66 \%$ & & & \\
\hline
\end{tabular}

tiplier in 1982 was 0.079 . During the past decade this difference was exceeded by multiplier developments only during 1974.

Column 4 in table 2 shows the simulated money stock levels for 1982 holding base growth at a constant 6.6 percent throughout 1982, and assuming that the money multiplier would have behaved exactly as it did. ${ }^{9}$ Two important results emerge from this simulation. First, the patterns of both monthly and quarterly M1 growth produced by the constant-base-growth approach (columns 5 and 6) are similar to those that actually occurred. For example, the very strong money growth observed in January would have been lessened

\footnotetext{
It might be argued that the actual money multiplier pattem would have been considerably different if the Federal Reserve actually had operated under such a control procedure. In this case, the resultan money growth would have been different from that reported here. This criticism is predicated on the belief that changes in base growth are assoctated with changes in the money multiplier. This belief is not well supported by recent data, however. For example, base growth was relatively stable in 1982, yet money maltiplier growth was more volatile than any year since 1974 . Moreover, for the period 1979 to 1982 , the cortelation between monthly base and multiplier growth is an insignificant 0.07 . Thus, money multiplier movements do not appear to be related signifcantly to monetary base growth.
}

only slightly by adopting a constant-base growth strategy (23.1 percent vs. 16.4 percent). M1 growth from January through July 1982 would have been even weaker than actually occurred (1.2 percent vs. 0.3 percent), and the strong $M 1$ growth from July to December 1982 would have been reduced only slightly (15.1 percent vs. 14.2 percent).

The similarity between actual and simulated MI growth for 1982 is not an aberration; base growth was indeed fairly stable last year. The volatility in M1 growth last year was attributable, in large part, to money multiplier developments, not erratic base growth. Thus, those critical of the Fed for the volatile money growth last year should recognize that a constant-base-growth strategy would not have mitigated this problem.

The second important finding is that MI growth from December 1981 to December 1982 would have exceeded the hypothetical target by 1.7 percentage points if the base had grown at a steady 6.6 percent over the year. The hypothetical growth rate target was 5.5 percent; M1 growth would have been about 7.2 percent under a policy of constant base growth. This "miss" of the annual Ml target occurred because the money multiplier essentially was unchanged between 
Table 3

M1 Growth Using Last Month's Multiplier as a Forecast of This Month's Multiplier (seasonally adjusted, original data)

\begin{tabular}{|c|c|c|c|c|c|c|}
\hline \multirow[b]{2}{*}{ Poriod } & \multirow[b]{2}{*}{ Targered 141} & \multirow[b]{2}{*}{ Actual nutipler } & \multirow[b]{2}{*}{ simulated base } & \multirow[b]{2}{*}{ Shmulated nt } & \multicolumn{2}{|c|}{ Simulated VI growth rate } \\
\hline & & & & & Monnu & Quarery \\
\hline & (1) & (2) & $(3)$ & (4) & (5) & (6) \\
\hline 1281 & & 2.5951 & & & & \\
\hline 1802 & $\$ 4429$ & 2.642 & $\$ 1707$ & $\$ 8462$ & $15,3 \%$ & \\
\hline 2802 & 44,9 & 25826 & 1702 & 439.5 & 16.6 & $70 \%$ \\
\hline 382 & 4468 & 2.5809 & 1700 & 4465 & 209 & \\
\hline 4182 & 448.8 & 25837 & 1739 & 4490 & ? 8 & \\
\hline $5 / 38$ & 45099 & 25566 & 174.5 & 4462 & 80 & 37 \\
\hline 682 & 4529 & 2,5374 & 1771 & 4486 & 9.2 & \\
\hline 782 & 4549 & 25354 & 1793 & 4545 & 142 & \\
\hline $8 \% 82$ & 4569 & 2,5388 & 1802 & 4575 & 82 & 92 \\
\hline 9882 & 4590 & 25598 & 1808 & 4628 & 948 & \\
\hline$\$ 0,02$ & 4610 & 25893 & 160. & 4663 & 95 & \\
\hline 1182 & 4601 & 2.6442 & 1789 & 4676 & 3.4 & 70 \\
\hline 1288 & 4651 & 26096 & 1779 & 4648 & 801 & \\
\hline Sinula & Gown' 6 & 1981 to Decen & $5,3 \%$ & & & \\
\hline
\end{tabular}

Biliens of dollars

December 1981 and December 1982, instead of declining at an assumed rate of 1.1 percent as it had on average over the preceding 10 years. Thus, both the pattern and average level of money growth last year were affected by unusual money multiplier developments, developments that would have had adverse impacts on a constant-base-growth rule.

\section{MONITORNG MONTWII MULTIP耳ER DVV}

The previous section demonstrates that short-run money multiplier movements must somehow be taken into account if more stable money growth is to be achieved. One way to accomplish this is to obtain one-month-ahead money multiplier forecasts and to adjust base growth to offset increases or decreases in the multiplier. Two ways of doing this are considered.

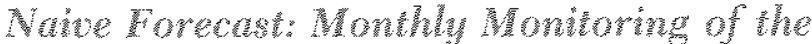 Whenther}

The simplest procedure to forecast next month's money multiplier is to assume that it will equal the current month's multiplier plus a random error $\left(\mu_{t}\right)$ which can be assumed to be zero on average: ${ }^{10}$

(2) $m_{t}=m_{t-1}+\mu_{t}$.

Once the multiplier is forecast, the amount of base needed to achieve the desired level of $\mathrm{MI}$ is then determined residually. For example, if the multiplier is forecast to be 2.60 next month and the target for MI next month is $\$ 450$ billion, the policy directive would be to achieve a $\$ 173.1$ billion $(\$ 450 / 2.60)$ base level next month. In this way, multiplier changes, to the extent that they are forecast, are offsef by altering the base to maintain a desired path for M1. If the multiplier were projected to be only 2.50 next month, for example, then this procedure would require $\$ 180$ billion $(\$ 450 / 2.50)$ in base to achieve the same $M 1$ target of $\$ 450$ billion.

Table 3 summarizes the results for 1982 using this technique to achieve the same steady 5.5 percent growth rate of $\mathrm{MI}$ as before. In comparison to the constant-base-growth strategy, monthly monitoring of

\footnotetext{
${ }^{10}$ See Balbach, "How Controllable is Money Growth?"
} 
multiplier developments mitigates both problems of excessive volatility and missing the annual objective. The variability in quarterly $\mathrm{Ml}$ growth is reduced substantially under the multiplier monitoring procedure (compare columns 6 in tables 2 and 3). In particular, this procedure would not have produced the sharp midyear slowdown in money growth relative to trend. The simulated money growth from I/1982 to III/1982 under this procedure would have been 6.4 percent, substantially higher than the 2.8 percent growth simulated under the constant-base-growth strategy.

Moreover, it also would have produced more stable quarterly growth in Ml last year than that simulated with the constant-base-growth strategy: the standard deviation of the quarterly growth rates is 6.76 for the constant-base-growth strategy and 2.27 for the procedure using naive multiplier forecasts. This increased quarterly stability is achicved, however, at the expense of slightly more volatile monthly money growth. For example, the standard deviation of the simulated monthly MI growth for the constant-base-growth approach was 10.21 ; the figure for the simulated MI growth using the multiplier forecast approach was 11.27 percent.

The increase in the monthly volatility of $\mathrm{Ml}$ growth is a direct consequence of the procedure itself; the monthly monitoring procedure achieves stable quarterly money growth by reacting quickly to unex pected monthly disturbances in the money multiplier. Thus, when the multiplier declined sharply in May, this procedure produced a swift policy response in terms of sharply increased base growth in subsequent months. Consequently, the money stock would have been much closer to the hypothetical target level in August than was the case with the constant-basegrowth strategy.

This simple procedure of controlling $\mathrm{MI}$ growth also is much more successful than the constant-basegrowth strategy in achieving the desired M1 growth target of 5.5 percent. Ml growth from December 1981 to December 1982 would have been 5.3 percent under this simple multiplier forecasting procedure, compared with a 7.2 percent growth rate under the constant-base-growth strategy.

If policy were directed toward achieving stable quarter-to-guarter Ml growth and strengthening the Fed's ability to hit an annual target, the simple technique of monetary control described here would be superior to the constant base-growth strategy. ${ }^{11}$

\section{Wone Sophishoned Mulnipler Tonecasts: The Series Techniques}

The forecasting technique described above - using last month's multiplier - is simple but ad hoc. There is no a priori reason to suspect that such a forecasting procedure would be especially reliable. Thus, more sophisticated time series forecasting models should be considered. ${ }^{12}$

Statistical evidence suggests that one can improve upon the preceding forecasting model, which merely uses last month's multiplier as a prediction for this month's multiplier. ${ }^{13}$ This improvement is derived by developing a time series model that explains changes in the multiplier (i.e., $m_{t}-m_{t-1}$ ) by using the information contained in the non-random component of the forecast errors from equation 2 . More formally, the time series model chosen is represented by

(3) $m_{t}-m_{t-\varepsilon}=\mu_{t}+b_{l} \mu_{t-1}$

\footnotetext{
"This operating procedure previously has been showt to reduce quarterly money volatility and better acheve the long-rum objective in 1980 (in Babach. "How Controlkble is Money Crowth") Similar gains also wonld have been achieved in 1981. Based on first-revised data and aiming for a December 1950 to December 1981 growth rate of 7.0 percent this procedure would have yielded 7.2 percent simulated growth, with the lowest quartery growth rate being 4.5 percent and the highest quarterly growth ate being 8.2 percent. The actual growth for this period was 6.4 percent, with the quartery growth rates ranging from 0.5 percent to 8.9 percent.

The following analysis continues in the tratition of Eduard J, Bomhof, "Predicting the Money Muttiplies" A Case Study for the U.S. and the Nether Iands, "Journal of Monetary Econonics Iuly $1977)$, pp. 325 45. James M. Johumes and Robert $H$. Rasche, "Predicting the Money Multiplier," Journal of Monetary Economics (July 1979), pp. 301-25; Johames and Rasche, "Can the Reserves Approach to Monetary Control Realy Work" and Michele Fratianni and Mustapha Nabli., "Money Stock Control in the EEC Conntries," Whaltwirtschafliches Archie (Heft 3:1979), pp. $401-23$.

${ }^{13}$ As a first step in such andysis, the autoconelation of the first difference in the money multiplier $\left(m_{t}-m_{t-1}\right)$ was examined for the period January 1959 to December 1981. For last month's multiplier to be an effective foreast of this nonth's multiplier, the change in the multiplier should wot be antocorrelated. Any evitence of autocorrelation suggests that there is information in the past history of the multiplier that could be used to improve the forecast
}

Examining the antocorrelation function of the multiplier's time series indicates that, for the sample period January 1959 to December 1981, the hypothesis that current changes in the multplier are independent of past changes can be rejected at the 5 percent significance level. 


\section{Table 4}

\section{M1 Growth Using One-Month-Ahead Money Multiplier Forecast Estimated Nodel: $m_{t}-m_{t-1}=0.002+\mu_{t}+0.196 \mu_{t-1}$ (seasonally adjusted, original data)}

\begin{tabular}{|c|c|c|c|c|c|c|c|}
\hline Period & Targered Mi & froulat & $\begin{array}{l}\text { morecast } \\
\text { mulples }\end{array}$ & sniutiated base? & Sinulated WT? & $\begin{array}{l}\text { suruate } \\
\text { montury }\end{array}$ & $\begin{array}{l}\text { growt } \\
\text { gurterty }\end{array}$ \\
\hline 1281 & $(1)$ & $\begin{array}{l}(2) \\
25951\end{array}$ & $(8)$ & $(4)$ & (5) & $(6)$ & (1) \\
\hline $1 / 82$ & 84429 & 26412 & 2.5914 & $\$ 1709$ & $\$ 4468$ & $173 \%$ & \\
\hline 2.82 & 4449 & 25826 & 26078 & 1706 & 4406 & 15.4 & $178 \%$ \\
\hline $8 \% 8$ & 446.8 & 25809 & 25855 & 1728 & 446,0 & 16.0 & \\
\hline $4 / 82$ & 448.8 & 25837 & 25798 & 1740 & 4495 & 97 & \\
\hline 5.82 & 4509 & 25566 & 25809 & 1747 & 4460 & 47.6 & 36 \\
\hline 682 & 4529 & 25374 & 25694 & 176.6 & 4490 & 6.5 & \\
\hline 782 & 454.9 & 25854 & 25397 & 1791 & 454.1 & 147 & \\
\hline 892 & 456.9 & 2.5380 & 25342 & 1803 & $457 \%$ & 10.0 & 82 \\
\hline 9,82 & 4590 & 25508 & 25350 & 1840 & 463.3 & 156 & \\
\hline 1082 & 4610 & 2.5890 & 25531 & 180.6 & 1676 & 11.6 & \\
\hline 1482 & 463. & 26142 & 25793 & 1795 & 4693 & 47 & 83 \\
\hline 1280 & $465 /$ & 26096 & 26049 & 1,786 & 4660 & 82 & \\
\hline Sirnule & Mr. Grovily De & $101,100 \% 1$ & erricer 198 & $7 \%$ & & & \\
\hline Actua & Grown De & en 196911 & enber 198 & $6 \%$ & & & \\
\hline
\end{tabular}

where $\mu_{t}$ is the error from equation 2 . An examination of the data revealed that the error in the multiplier process last month $\left(\mu_{i-1}\right)$ exerted a statistically significant effect on the change in the multiplier for this month. Moreover, the analysis indicated the existence of a slight negative trend in the data. Using this extra information and estimating the appropriate version of equation 3 for the period January 1959 to December 1981 yielded the following results:

(4) $\mathrm{m}_{\mathrm{t}}-\mathrm{m}_{\mathrm{t}-1}=-0.002+\mu_{\mathrm{t}}+0.196 \mu_{\mathrm{t} \ldots 1}$

where again $\mu_{t}$ represents the random, unforeseen "innovation" to the multiplier process. ${ }^{14}$

While, for this sample, equation 4 is statistically a

\footnotetext{
${ }^{14}$ All data are seasonally adjusted. The estimated standart error of the model is 0.00118 and the Ljung-Box Q-statistic $Q(12)$ distributed as a $x^{2}$ with 10 degrees of freedom, is 11.53 . Because the reported $Q$-statistic is even less than the 30 percent critical value $\left(x^{2}=11.80\right)$, the hypothesis of independent residuals cannot be rejected, even at this high level.

For further details on this approad to forecasting economic time series, see C. W. J. Granger and Paul Newbold, Forecasting Economic Time Series (Academic Press, 1977).
}

more reliable model of the multiplier than the naive model used in the previous section, there is really little substantive difference between the two models. The naive model (equation 2) suggests that changes in the multiplier are random disturbances $\left(\mu_{\mathrm{t}}\right)$, while the time series model (equation 4) only adds a negative trend term and the impact of last period's disturbance $\left(\mu_{t-1}\right)$. Thus, there may well be little difference in the forecasts.

The results found in table 4 suggest that this is indeed the case. The time-series model given by equation 4 was used to forecast the monthly values of the multiplier for 1982 by continuously updating the forem cast to incorporate last month's money multiplier developments. The one-step-ahead money multiplier forecasts are listed in column 3. The table also shows the amount of base injection (column 4) required each month to achieve the hypothetical 5.5 percent $\mathrm{Ml}$ growth path if the multiplier behaved as the time series model predicted. In addition, the table lists the level and growth of M1 that would have resulted from the simulated base injections had the multiplier behaved as it actually did (columns 5,6 and 7 ). 
The simulated money growth developments using this procedure are similar to those using the naive forecast strategy (see table 3). For example, the aver" age monthly $\mathrm{Ml}$ growth simulated in table 4 is 5.9 percent; the comparable figure using the naive model (table 3, column 5) is 6.2 percent. The quarterly simulations are also similar; in particular, the two successive quarters of very weak money growth simulated under the constant-base-growth strategy are avoided by either of these forecasting procedures.

Because the multiplier forecasts derived from the naive and sophisticated models are not that different, the lessons learned from the naive model results are supported by the evidence found in table 4 for the more sophisticated model. ${ }^{15}$ In particular, this multiplier forecasting procedure comes closer than the constant-base-growth strategy to achieving the hypothetical Ml growth target. In addition, quarterly volatility in money growth is reduced substantially using

\footnotetext{
${ }^{15}$ While the $1959-81$ sample period results indicate some statistical gain over the naive model in explaining changes in the multiplier, the forecasting experience from 1982 shows that, as a practical matter, little would have been gained from employing the more sophisticated model. This is a limited sample on which to draw, however, and one should not conclude that the simple no-change model is equally sufficient in all time periods.
}

either multiplier forecasting technique. ${ }^{16}$ Thus, if quarterly money growth fluctuations affect real economic activity as suggested earlier, the multiplier forecasting approach to conducting monetary policy appears superior to the constant base-growth strategy.

\section{CONCUSTON}

Monetary policy actions that utilize a constant-basegrowth procedure generally will not achieve stable short-run money growth. A post-mortem of 1982 money growth indicates that much of the volatility in money growth last year was attributable to money multiplier fluctuations, not erratic monetary base growth. Consequently, monetary policy aimed at smoothing the growth of Ml must anticipate and react to multiplier movements. This article shows that either a naive approach to multiplier predictions or a more sophisticated time series model would have enabled policymakers to achieve smoother quarter-to-quarter changes in Ml by varying the growth of the adjusted base to offset changes in the multiplier.

\footnotetext{
${ }^{6}$ For an earlier analysis of this type that reaches similar condusions, see Albert E. Burger, "The Relationship Between Monetary Base and Money: How Close?" this Review (October 1975), pp. 3-8.
}

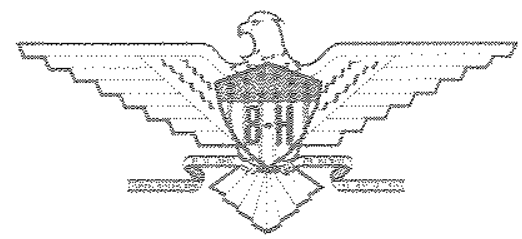

